\title{
Effects of Deoxynivalenol on Content of Chloroplast Pigments in Barley Leaf Tissues
}

\author{
W. R. Bushnell, P. Perkins-Veazie, V. M. Russo, J. Collins, and T. M. Seeland
}

First author: Cereal Disease Laboratory, U.S. Department of Agriculture, Agricultural Research Service, St. Paul, MN 55108; second, third, and fourth authors: South Central Agricultural Research Laboratory, U.S. Department of Agriculture, Agricultural Research Service, Lane, OK; and fifth author: Department of Plant Pathology, University of Minnesota, St. Paul, MN 55108.

Accepted for publication 31 August 2009.

\begin{abstract}
Bushnell, W. R., Perkins-Veazie, P., Russo, V. M., Collins, J., and Seeland, T. M. 2010. Effects of deoxynivalenol on content of chloroplast pigments in barley leaf tissues. Phytopathology 100:33-41.

To understand further the role of deoxynivalenol (DON) in development of Fusarium head blight (FHB), we investigated effects of the toxin on uninfected barley tissues. Leaf segments, 1 to $1.2 \mathrm{~cm}$ long, partially stripped of epidermis were floated with exposed mesophyll in contact with DON solutions. In initial experiments with the leaf segments incubated in light, DON at 30 to $90 \mathrm{ppm}$ turned portions of stripped tissues white after 48 to $96 \mathrm{~h}$. The bleaching effect was greatly enhanced by addition of 1 to $10 \mathrm{mM} \mathrm{Ca}^{2+}$, so that DON at 10 to $30 \mathrm{ppm}$ turned virtually all stripped tissues white within $48 \mathrm{~h}$. Content of chlorophylls a and $\mathrm{b}$ and of total carotenoid pigment was reduced. Loss of electrolytes and uptake of Evans blue indicated that DON had a toxic effect, damaging plasmalemmas in treated tissues before chloroplasts began to lose
\end{abstract}

ABSTRACT pigment. When incubated in the dark, leaf segments also lost electrolytes, indicating DON was toxic although the tissues remained green. Thus, loss of chlorophyll in light was due to photobleaching and was a secondary effect of DON, not required for toxicity. In contrast to bleaching effects, some DON treatments that were not toxic kept tissues green without bleaching or other signs of injury, indicating senescence was delayed compared with slow yellowing of untreated leaf segments. Cycloheximide, which like DON, inhibits protein synthesis, also bleached some tissues and delayed senescence of others. Thus, the effects of DON probably relate to its ability to inhibit protein synthesis. With respect to FHB, the results suggest DON may have multiple roles in host cells of infected head tissues, including delayed senescence in early stages of infection and contributing to bleaching and death of cells in later stages.

Additional keywords: trichothecene toxin.
Fusarium graminearum, the principal cause of Fusarium head blight (FHB) in North America, is a necrotrophic pathogen, causing browning, bleaching, and premature death of barley and wheat heads $(6,31,45)$. Grain yield and quality are reduced significantly $(43,45)$. In the course of disease development, the fungus produces lesions in florets of the barley or wheat head. In barley, these may be entirely brown or have yellow or white centers surrounded by a brown ring $(6,31)$. In heavily infected heads, lesions enlarge and coalesce to cover entire florets.

As FHB develops, $F$. graminearum produces deoxynivalenol (DON) and other trichothecene toxins that can accumulate to toxic levels, reducing suitability of grain for use by nonruminant animals and humans $(11,15)$. DON is an inhibitor of protein synthesis in eukaryotic organisms and has been shown to induce programmed cell death (PCD) in mammalian cells $(40,42)$. The toxicity of DON and other trichothecene toxins to plants has been shown by yellowing, browning, and necrosis of toxin-treated tissues $(10,12,38)$. In addition, uptake of trypan blue (14) and electrolyte loss $(9,29,30)$ indicate damage to plasmalemmas. DON also inhibits growth of wheat or Arabidopsis as measured in roots, coleoptiles, or callus cultures $(5,10,34,35,44)$ and inhibits mitosis and cell division in roots (39).

The effects of DON in plants are often attributed to its ability to inhibit protein synthesis. DON inhibits protein synthesis in maize

Corresponding author: W. R. Bushnell; E-mail address: billb@umn.edu

doi:10.1094/PHYTO-100-1-0033

This article is in the public domain and not copyrightable. It may be freely reprinted with customary crediting of the source. The American Phytopathological Society, 2010. and wheat tissues $(8,42)$. In mammalian leukocytes, DON induces signaling pathways leading to PCD and also to immune responses (40). In both cases, DON binds to target sites on ribosomes. In line with this, sensitivity to DON in protoplasts, cells, and tissues of tobacco was reduced when the target sites were modified in transgenic plants $(16,25,37)$.

The toxic effects of DON suggest it has a role in FHB pathogenesis. Mutants of $F$. graminearum unable to produce DON or other trichothecene toxins initiated disease in wheat or barley heads, but had reduced ability to develop within heads $(11,13,18)$, resulting in reduced necrosis and bleaching (4). In line with this, a mutant of $F$. graminearum, unable to produce toxin, was stopped by host wall thickenings, a defense response in the rachis of wheat heads (26). A toxin-producing strain inhibited formation of the wall thickenings, allowing the fungus to spread in the head. Overall, however, the cytological, physiological, and molecular effects of DON in either healthy or diseased tissue are not described sufficiently to reveal in what ways the toxin may promote disease development.

Toward a more complete understanding of the complex effects of DON in plant tissues and the roles the toxin plays in FHB, we observed changes induced by DON in detached barley leaf segments. In initial experiments, the toxin turned some tissues white as if it had a specific effect on chloroplast pigments. However, results were highly variable and DON sometimes had an opposite effect, preserving instead of reducing leaf pigmentation. Here we describe both of these effects of DON as well as experimental factors that influenced DON activity. We also investigated leakage of electrolytes and uptake of Evans blue as indicators of damage to the plasmalemma in relation to effects of DON on chlorophyll content. 


\section{MATERIALS AND METHODS}

Preparation and treatment of leaf segments. Experiments were done with primary leaves of Hordeum vulgare, cv. Robust, which is susceptible to FHB. The plants were grown from seed in a germination mix (Strong-Lite, Pine Bluff, AR) or a composted greenhouse soil in 7.5 or $10 \mathrm{~cm}$ plastic pots in a chamber with $16 \mathrm{~h}$ /day of $\mathrm{HO}$ and $\mathrm{VHO}$ cool white fluorescent light at 140 to $160 \mu \mathrm{mol} \mathrm{m} \mathrm{s}^{-1}$, as measured at the top of pots. Temperature was $21 \pm 2{ }^{\circ} \mathrm{C}$. Seven days after planting, primary leaves were harvested and treated with toxin generally as described by Tada et al. (46). Epidermis was stripped with forceps from portions of the abaxial leaf surface, exposing mesophyll over $1 / 3$ to $1 / 2$ of leaf surface on each side of the midrib, which was not stripped. One to three segments 1.0 to $1.2 \mathrm{~cm}$ long were cut from each leaf, avoiding $1 \mathrm{~cm}$ at the leaf tip and any poorly stripped areas elsewhere. The segments were floated with the stripped surface down on $1 \mathrm{ml}$ of test solution in glass dishes $2.5 \mathrm{~cm}$ in diameter and $0.8 \mathrm{~cm}$ high, or in some later experiments, in wells $2.5 \mathrm{~cm}$ in diameter and $2.1 \mathrm{~cm}$ high in 12-well polystyrene cell culture plates (Costar \#3512 cell culture plate, Fisher, Chicago), which gave results similar to those in glass dishes. Three segments were placed in each dish or well. For incubation, the glass dishes (without covers) were placed in covered $9 \mathrm{~cm}$ petri dishes; lids on the 12-well plates were closed. The covered dishes and wells were incubated in a plant growth chamber (Model E54U; Percival, Boone, IA) under cool white fluorescent light at 150 to $170 \mu \mathrm{mol} \mathrm{m} \mathrm{m}^{-2} \mathrm{~s}^{-1}$ and incandescent light at $70 \mu \mathrm{mol} \mathrm{m}{ }^{-2} \mathrm{~s}^{-1}$, totaling 220 to $250 \mu \mathrm{mol} \mathrm{m} \mathrm{m}^{-2} \mathrm{~s}^{-1}$. Lights were on for $16 \mathrm{~h}$ each day. Chamber temperature was $22 \pm$ $1^{\circ} \mathrm{C}$. Temperature within petri dishes was $25 \pm 1^{\circ} \mathrm{C}$ when lights were on and $23 \pm 1{ }^{\circ} \mathrm{C}$ in dark periods, as measured with a shaded mercury bulb thermometer inserted horizontally through a hole in the side of a dish. A few experiments were done in a Model E15 plant growth chamber (Conviron, Winnipeg, Manitoba) with temperature and light adjusted to be the same as in the Percival chamber.

DON was used at 10 to $90 \mathrm{ppm}(\mu \mathrm{g} / \mathrm{ml})$, equal to 33.7 to $303 \mu \mathrm{M}$. Cycloheximide was used at 30 to $90 \mathrm{ppm}$, equal to 107 to $320 \mu \mathrm{M}$. These and other components of test solutions were from Sigma-Aldrich (St. Louis, MO), except $\mathrm{CaCl}_{2}$ was from Fisher Scientific (Fairlawn, NJ). Solutions were prepared with water from a Milli-Q water purification system (Millipore Corp., Billerica, MA).

A typical experiment consisted of 96 leaf segments in 32 dishes or wells treated with four concentrations of DON. For each DON concentration, six leaf segments were collected for observation and analysis on each of 4 days after the start of treatment. For each day, segments representative of each treatment were photographed with a Minolta SRT 201 camera outfitted with a Rokker bellows. The photos were taken under incandescent light with Kodak T $35 \mathrm{~mm}$ color slide film. Photos were processed digitally for publication.

Chloroplast pigments. Relative chloroplast content was measured in intact stripped leaf segments with a chlorophyll content meter (Model CCM-200, OptiSciences, Tyngsboro, MA). This gave light absorbance at $660 \mathrm{~nm}$, largely due to chlorophyll a, corrected for differences in leaf thickness and other factors affecting light absorbance, as determined by absorbance at $940 \mathrm{~nm}$. The 10 -mm-diameter circular orifice of the meter was covered with a disc of X-ray film, which had a $5 \times 8 \mathrm{~mm}$ rectangular opening to delineate a zone used to measure chlorophyll content. The opening exposed portions of stripped and midrib areas of leaf segments for measurement. Except for the opening, the disc was covered with black adhesive shelf paper to block unwanted light.

For each experiment, relative chlorophyll content was calculated as the mean value for six leaf segments per treatment at each sampling time. Experiments usually were replicated two to eight times (as indicated) at intervals of one to several weeks. Results are given as mean \pm standard error (S.E.) based on values among replicated experiments. Significance of differences among DON treatments in mean chlorophyll content of leaf segments was determined by two-way analysis of variance and Tukey multiple comparisons using R software (R Development Core Team, 2007; R Foundation for Statistical Computing, Vienna, Austria). Using data for all sampling times, each treatment (DON concentration) was paired with each of the other treatments within an experiment to find pairs with significant differences at $P=0.05$.

Content of chlorophyll a, chlorophyll b, and carotenoid pigments was measured spectrophotometrically in leaf segment extracts. For this, leaf segments were prepared and treated with DON as described earlier, but 12 segments (instead of six) were prepared for each sampling time of a given treatment. The segments were removed from incubation dishes, blotted dry with filter paper, placed in $2 \mathrm{ml}$ capped cryovial tubes, stored 1 to 11 days in a freezer at $-80^{\circ} \mathrm{C}$, and shipped frozen to the ARSUSDA South Central Agricultural Research Laboratory, Lane, $\mathrm{OK}$, for spectrophotometric measurement of chlorophylls $\mathrm{a}$ and $\mathrm{b}$ and total carotenoids. Abbreviated methods of Lichtenthaler and Buschmann (32) were used. For each measurement, two to three leaf segments (totaling 20 to $34 \mathrm{mg}$ fresh weight) from each cryovial were weighed, combined with $2 \mathrm{ml}$ of cold $100 \%$ acetone, and ground with mortar and pestle. The resulting slurry was transferred to a graduated centrifuge tube and brought to $5 \mathrm{ml}$ with cold $100 \%$ acetone. The tubes were capped tightly and centrifuged for $5 \mathrm{~min}$ at $500 \times g$ at room temperature. Supernatant, free of cellular debris, was transferred to $1 \mathrm{~cm}$ glass cuvettes and read on a scanning spectrophotometer (Shimadzu Model UV 160, Shimadzu, Columbia, MO). Absorbance was measured at 5 wavelengths: $750 \mathrm{~nm}$ for haze, $662 \mathrm{~nm}$ for chlorophyll a, $645 \mathrm{~nm}$ for chlorophyll b, $520 \mathrm{~nm}$ for pheophytins (browning compounds), and $470 \mathrm{~nm}$ for carotenoids. Pheophytin concentrations were below critical levels. The spectrophotometric separations of carotenoids were verified by high performance liquid chromatography. Amounts of chlorophylls $\mathrm{a}$ and $\mathrm{b}$ and total carotenoids were calculated using the formulas of Lichtenthaler and Buschmann (32). Two samples each with two to three segments were analyzed from a given cryovial. Reported results are based on the means for these duplicate samples.

Conductivity. To measure electrolyte loss from treated leaf segments, we measured electrical conductivity of solutions on which three segments per dish were incubated. Solution from each dish was diluted to $20 \mathrm{ml}$ and conductivity measured as $\mu \mathrm{mho} / \mathrm{cm}$ with a conductivity bridge (Industrial Instruments, Model RC 16B2) and a conductivity cell with S.I. constant $1.0 \mathrm{~cm}$ (Model 3403, YSI Hydrodata Ltd., Letchworth, UK). For each experiment, conductivity was measured for the solution in one dish for each DON concentration at each sampling time. The mean \pm S.E. is reported for three to six replicated experiments, except for single values from an experiment with $\mathrm{Ca}\left(\mathrm{NO}_{3}\right)_{2}$ added to DON solutions. Differences among treatments in replicated experiments were analyzed for significance as described for relative chlorophyll content.

Evans blue staining. DON-treated leaf segments were stained with Evans blue, as used to detect dead or dying cells by uptake of the dye (20). Leaf segments were removed from DON solutions and incubated stripped side down for 20 to $30 \mathrm{~min}$ on $0.1 \%$ (wt/vol) aqueous Evans blue (Sigma-Aldrich) in $2.5 \mathrm{~cm}$ dishes. Leaf segments were washed briefly three times in water and mounted under a cover glass on a glass slide for observation. Mesophyll in stripped areas of leaf segments was observed with a Zeiss Standard bright field light microscope. A long working distance 40× objective lens (Nikon M Plan 40 0.5 ELWD) was used with $10 \times$ eyepieces, giving a field of view of $0.58 \mathrm{~mm}$ in diameter. Each leaf segment was examined at six sites in each of four rows within areas from which epidermis was removed. For each of the 24 sites, we counted the number of mesophyll cell lobes stained with Evans blue and total number of lobes. The use 
of lobes instead of entire cells is explained in the Results section. For an individual experiment, the mean percentage of stained lobes was determined for two leaf segments. Reported values are for the means for three to seven such experiments. In addition, photos of representative fields of view were taken with a Nikon DXM 1200 digital camera.

DON content in treated leaf segments. Leaf segments were analyzed for DON using gas chromatography/mass spectrometry
(GC/MS), as described by Mirocha et al. (36) for single kernel analysis. Each sample consisted of three partially stripped leaf segments which were incubated on DON solutions for 12 or $48 \mathrm{~h}$. Segments were blotted dry, weighed, and frozen. After 1 to 3 weeks, segments were extracted in acetonitrile-water (84:16, $\mathrm{vol} / \mathrm{vol}$ ), cleaned, derivatized, and analyzed in a QP2010 GC/MS system (Shimadzu, Kyoto). The temperature program, which differed slightly from Mirocha et al. (36), was isothermal at

\section{LIGHT}

$\mathrm{H}_{2} \mathrm{O}$

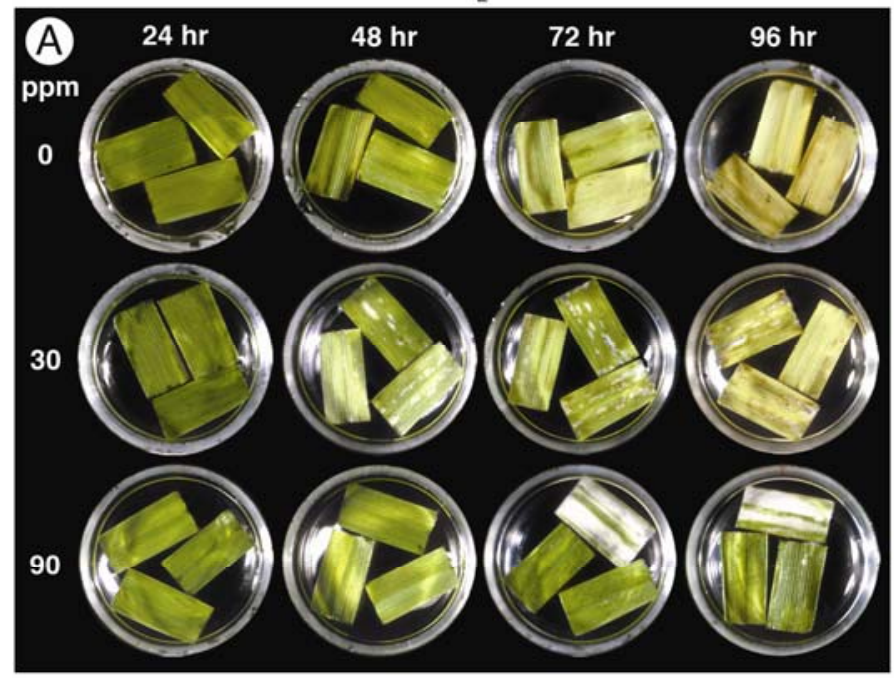

$\mathrm{H}_{2} \mathrm{O}$

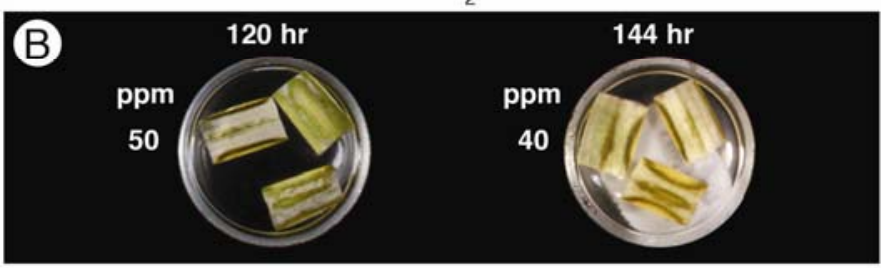

$\mathrm{H}_{2} \mathrm{O}$

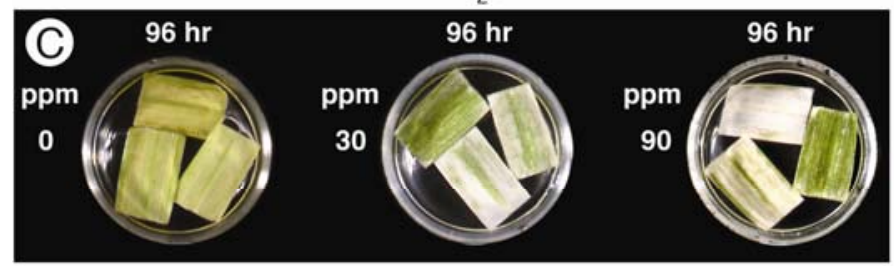

$\mathrm{Ca}\left(\mathrm{NO}_{3}\right)_{2}$
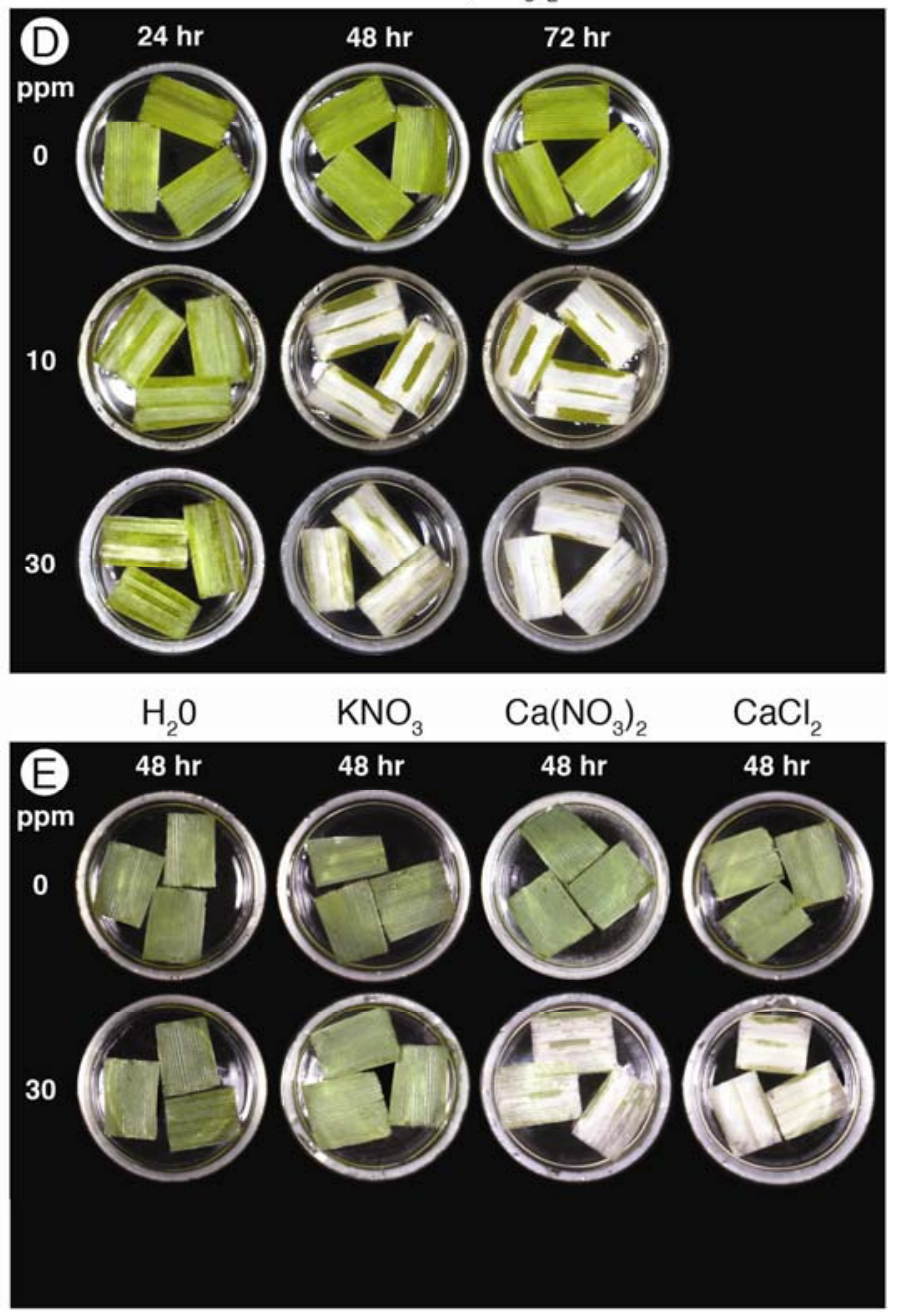

DARK

$\mathrm{H}_{2} \mathrm{O}$

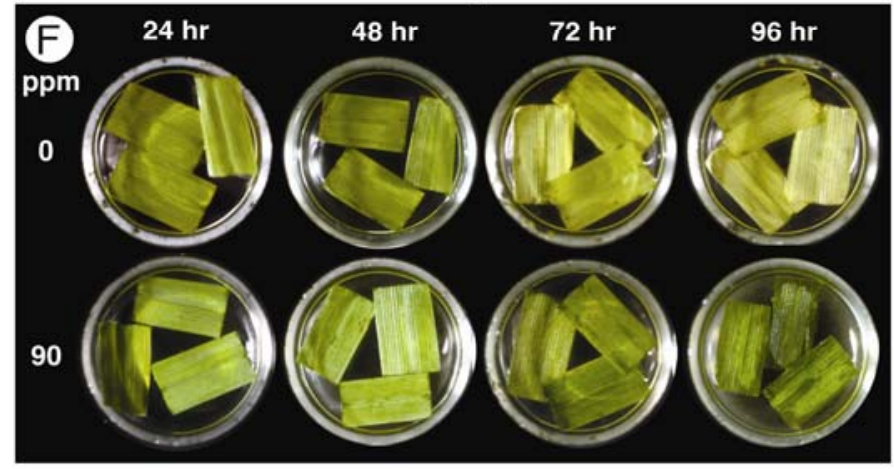

$\mathrm{Ca}\left(\mathrm{NO}_{3}\right)_{2}$

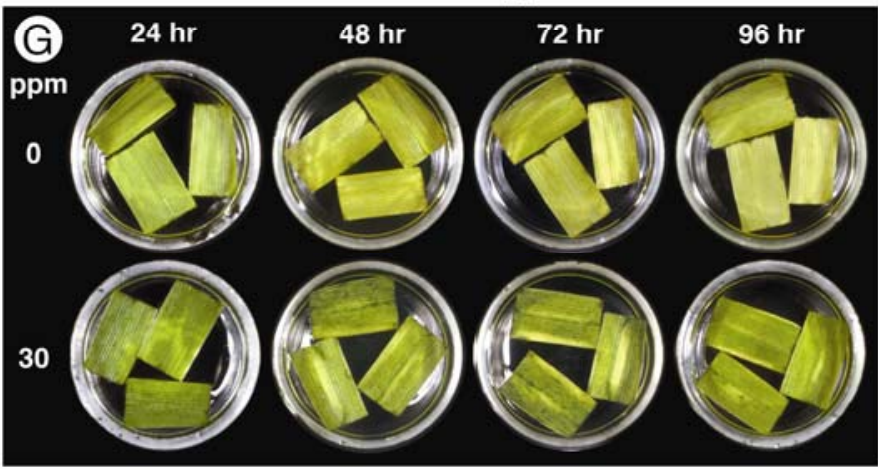

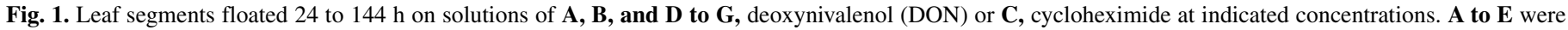

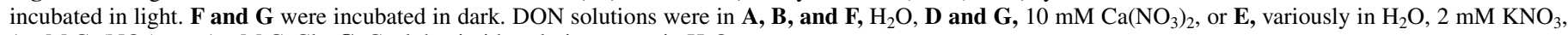
$1 \mathrm{mM} \mathrm{Ca}\left(\mathrm{NO}_{3}\right)_{2}$, or $1 \mathrm{mM} \mathrm{CaCl}_{2}$. C, Cycloheximide solutions were in $\mathrm{H}_{2} \mathrm{O}$. 
$150^{\circ} \mathrm{C}$ for $1 \mathrm{~min}$, ramped at $30^{\circ} \mathrm{C} / \mathrm{min}$ to $280^{\circ} \mathrm{C}$, and held at that temperature for $4 \mathrm{~min}$. Fragment ions at $\mathrm{m} / \mathrm{z} 235.10,259.10$, 295.1, and 422.10 were used for selected ion monitoring. For quantification, a 10 point standard curve for 0.025 to $15 \mathrm{ng} / \mu \mathrm{l}$ DON was based on fragment ion 235.10. The DON standard was from Sigma-Aldrich. DON concentrations are given as ppm based on fresh weight of leaf segments. Mean values \pm S.E. for each combination of applied DON and time of sampling are based on three replicated determinations from a single experiment.

\section{RESULTS}

To follow changes in relation to DON concentrations, we observed and photographed DON-treated leaf segments at $24 \mathrm{~h}$ intervals for $96 \mathrm{~h}$. Presented first are experiments with segments incubated in light followed by results in darkness. Both were done with and without $\mathrm{Ca}\left(\mathrm{NO}_{3}\right)_{2}$, which had pronounced effects on results in light.

Incubation in light without $\mathrm{Ca}\left(\mathrm{NO}_{3}\right)_{2}$. Control leaf segments on 0 ppm DON without $\mathrm{Ca}\left(\mathrm{NO}_{3}\right)_{2}$ became chlorotic, losing virtually all visible chlorophyll by $96 \mathrm{~h}$, as the segments became senescent after being detached from plants (Fig. 1A). DON at $10 \mathrm{ppm}$ had no effect on this loss of chlorophyll in any of several trials. DON at $30 \mathrm{ppm}$ induced scattered white spots and streaks at 48 to $72 \mathrm{~h}$ but also kept intervening areas greener than tissues in control segments through $72 \mathrm{~h}$ (Fig. 1A). DON at $90 \mathrm{ppm}$ turned the entire stripped areas of some segments white at 72 to $96 \mathrm{~h}$ leaving tissues green in unstripped areas near the midrib and leaf edges (Fig. 1A). The white tissues appeared to lose virtually all chlorophyll and carotenoid pigment. However, other leaf segments at $90 \mathrm{ppm}$ remained entirely green, often in the same incubation dish with white segments as shown for 72 and $96 \mathrm{~h}$ (Fig. 1A). These segments appeared to remain as green as seg- ments were at $24 \mathrm{~h}$. Thus, DON at $90 \mathrm{ppm}$ had a twofold effect, causing loss of green and yellow pigments on one hand and retention of green on the other.

In several experiments with 20 to $90 \mathrm{ppm}$, DON gave white patches most consistently at 40 to $60 \mathrm{ppm}$ (data not shown). The white patches were accompanied by water soaking in some segments, an indication that the treatment was toxic. However, DON concentrations of 70 to $90 \mathrm{ppm}$ protected some segments against water soaking in addition to keeping segments green. In leaf segments incubated for extended periods (120 to $144 \mathrm{~h}$ ) with DON at 40 to $50 \mathrm{ppm}$, tissues bordering white stripped areas sometimes turned reddish brown or dark brown (Fig. 1B). Unstripped tissues outside the border were chlorotic.

Leaves in most experiments were incubated at light intensity of 220 to $250 \mu \mathrm{mol} \mathrm{m} \mathrm{m}^{-2} \mathrm{~s}^{-1}$. Results were similar with $150 \mu \mathrm{mol} \mathrm{m} \mathrm{m}^{-2} \mathrm{~s}^{-1}$ but at $450 \mu \mathrm{mol} \mathrm{m} \mathrm{m}^{-2} \mathrm{~s}^{-1}$, white areas developed sooner and more abundantly than at lower intensities (data not shown). However, variation remained high at this high light intensity and temperature in incubating dishes could not be controlled adequately.

Cycloheximide, which like DON is an inhibitor of protein synthesis in eukaryotic cells (47), had effects on leaf segments much like those of DON. At 30 or $90 \mathrm{ppm}$, cycloheximide produced extensive white patches in segments incubated in light for $96 \mathrm{~h}$ (Fig. 1C). Again, nonwhite portions of leaf segments remained greener than water-incubated control segments which became chlorotic. Chloramphenicol, an inhibitor of protein synthesis in chloroplasts and prokaryotic organisms had little or no visible effect on leaf segments (data not shown).

Incubation in light with $\mathbf{C a}\left(\mathrm{NO}_{3}\right)_{2}$. The bleaching effect of DON was markedly increased by addition of $\mathrm{Ca}\left(\mathrm{NO}_{3}\right)_{2}$ to $\mathrm{DON}$ solutions. Over a range of 0.1 to $100 \mathrm{mM}, \mathrm{Ca}\left(\mathrm{NO}_{3}\right)_{2}$ promoted loss of chlorophyll by $30 \mathrm{ppm}$ DON (data not shown). The largest differences between DON-treated and control segments occurred

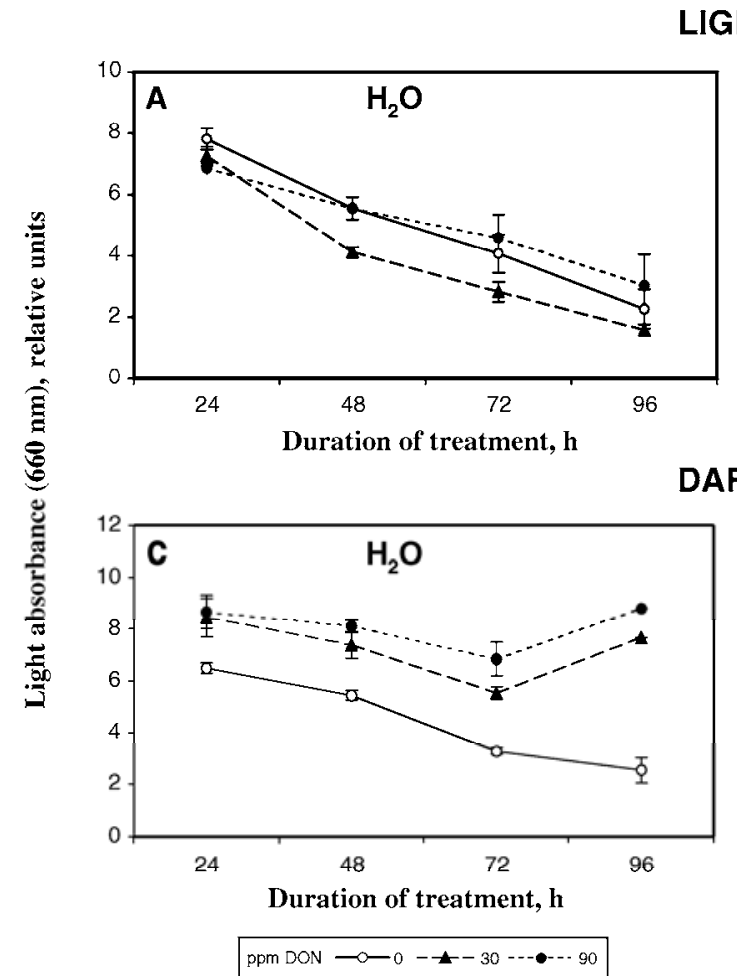

LIGHT

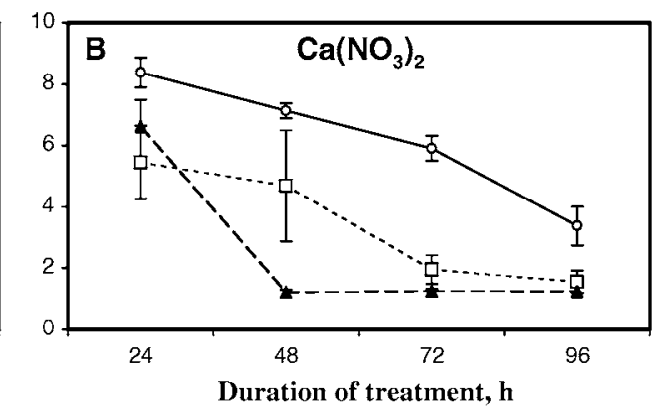

DARK

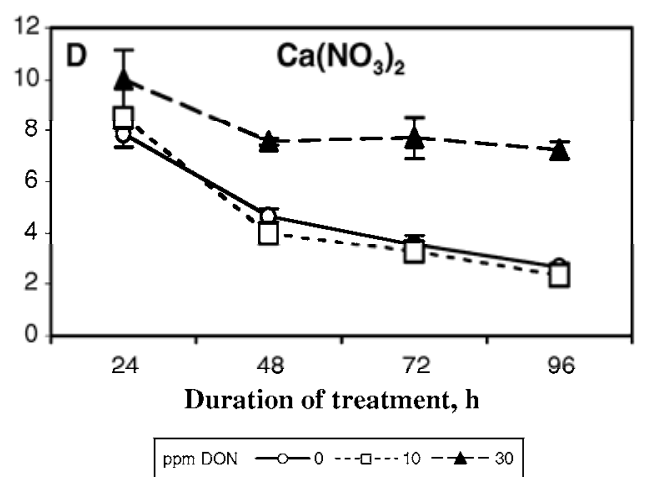

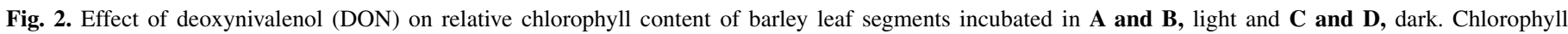

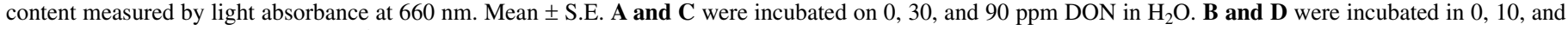

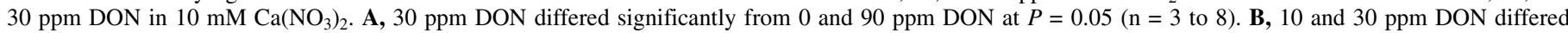

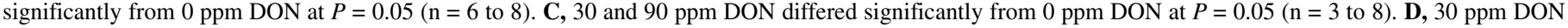

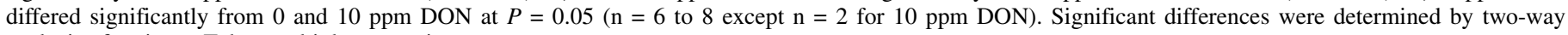
analysis of variance-Tukey multiple comparisons. 
most consistently at $10 \mathrm{mM}$, the concentration used in most experiments reported here. With $10 \mathrm{mM} \mathrm{Ca}\left(\mathrm{NO}_{3}\right)_{2}$, DON at both 10 and $30 \mathrm{ppm}$ caused complete loss of color by 48 to $72 \mathrm{~h}$ as assessed visually in stripped areas of leaf segments (Fig. 1D). Thus, DON at $10 \mathrm{ppm}$, which had no effect without $\mathrm{Ca}\left(\mathrm{NO}_{3}\right)_{2}$, was highly effective with $\mathrm{Ca}\left(\mathrm{NO}_{3}\right)_{2}$. Apart from promoting loss of chlorophyll pigments in response to $\mathrm{DON}, \mathrm{Ca}\left(\mathrm{NO}_{3}\right)_{2}$ partially delayed chlorosis of control leaf segments incubated in light without DON (Fig. 1D).

$\mathrm{CaCl}_{2}$ was as effective as $\mathrm{Ca}\left(\mathrm{NO}_{3}\right)_{2}$ in promoting DON-induced loss of leaf pigments as observed visually at $48 \mathrm{~h}$ (Fig. $1 \mathrm{E}$ ). $\mathrm{KNO}_{3}$ did not promote DON-induced loss of leaf pigments (Fig. 1E) but in the absence of DON, delayed yellowing (data not shown) much as described for $\mathrm{Ca}\left(\mathrm{NO}_{3}\right)_{2}$ earlier. The results indicate that $\mathrm{Ca}^{2+}$ promoted DON-induced pigment loss, whereas $\mathrm{NO}_{3}^{-1}$ retarded chlorophyll loss in absence of DON.

Incubation in the dark without $\mathrm{Ca}\left(\mathrm{NO}_{3}\right)_{2}$. Control leaf segments incubated for 72 to $96 \mathrm{~h}$ in the dark on $\mathrm{H}_{2} \mathrm{O}$ without either DON or $\mathrm{Ca}\left(\mathrm{NO}_{3}\right)_{2}$ became chlorotic (Fig. $\left.1 \mathrm{~F}\right)$, much as in light. On both 30 and 90 ppm DON, the loss of green pigmentation was prevented, as shown for $90 \mathrm{ppm}$ (Fig. 1F). No white patches developed on either 30 or 90 ppm DON. However, some of the green leaf segments on $90 \mathrm{ppm}$ DON became limp and showed water soaking by $96 \mathrm{~h}$ (Fig. 1F). As described later, electrolyte loss indicated tissues were damaged by DON in both light and dark, even though tissues in the dark retained most of their chlorophyll. Cycloheximide at 30 to $60 \mathrm{ppm}$ likewise retarded loss of green pigment in the dark and caused some water soaking (data not shown).

Incubation in the dark with $\mathrm{Ca}\left(\mathrm{NO}_{3}\right)_{2}$. With $\mathrm{Ca}\left(\mathrm{NO}_{3}\right)_{2}$ added to $30 \mathrm{ppm}$ DON, chlorophyll was usually retained in the dark (Fig. 1G) much as without $\mathrm{Ca}\left(\mathrm{NO}_{3}\right)_{2}$. Some tissues treated with DON again became water soaked and limp although without showing any bleached areas. In the dark, unstripped midrib portions of leaf segments seemed unaffected by DON as they became chlorotic without signs of injury, much like entire segments incubated without DON (Fig. $1 \mathrm{G}) . \mathrm{Ca}\left(\mathrm{NO}_{3}\right)_{2}$ without DON did not retard development of chlorosis in the dark as it had in light. Leaf segments yellowed by 72 to $96 \mathrm{~h}$, as shown for $0 \mathrm{ppm}$ DON (Fig. 1G).

Relative chlorophyll content. To confirm visual observations, we measured relative content of chlorophyll by absorbance of light in leaf segments. By $96 \mathrm{~h}$, leaf segments incubated in light without DON or $\mathrm{Ca}\left(\mathrm{NO}_{3}\right)_{2}$ lost about $2 / 3$ of the chlorophyll present at $24 \mathrm{~h}$ (Fig. 2A). DON at $90 \mathrm{ppm}$ without $\mathrm{Ca}\left(\mathrm{NO}_{3}\right)_{2}$ had a negligible effect on this decline in chlorophyll content (Fig. 2A), although the treatment produced a mixture of white spots intermingled with tissue that appeared greener than controls as described earlier. On the other hand, DON at $30 \mathrm{ppm}$ reduced chlorophyll content compared with treatments without DON (Fig. 2A), commensurate with presence of white spots and yellowing of other tissues.

$\mathrm{Ca}\left(\mathrm{NO}_{3}\right)_{2}$ accelerated DON-induced reduction in chlorophyll content in light (Fig. 2B). With DON at $30 \mathrm{ppm}$, most of the chlorophyll was gone by $48 \mathrm{~h}$. With $10 \mathrm{ppm}$ DON, most was gone by $72 \mathrm{~h}$. As noted earlier, 10 ppm DON without $\mathrm{Ca}\left(\mathrm{NO}_{3}\right)_{2}$ had no visible effect in any of several trials. However, $\mathrm{Ca}\left(\mathrm{NO}_{3}\right)_{2}$ without DON tended to slow reduction in chlorophyll content (Fig. 2B) compared with controls on $\mathrm{H}_{2} \mathrm{O}$ alone (Fig. 2A).

In darkness, leaf segments on 30 to 90 ppm DON without $\mathrm{Ca}\left(\mathrm{NO}_{3}\right)_{2}$ retained chlorophyll near initial values for $96 \mathrm{~h}$ (Fig. $2 \mathrm{C}$ ), confirming visual assessments. With $\mathrm{Ca}\left(\mathrm{NO}_{3}\right)_{2}$, DON at $30 \mathrm{ppm}$ was also effective in maintaining chlorophyll content (Fig. 2D). However, 10 ppm DON with $\mathrm{Ca}\left(\mathrm{NO}_{3}\right)_{2}$ was ineffective as was $\mathrm{Ca}\left(\mathrm{NO}_{3}\right)_{2}$ applied alone (Fig. 2D). The results confirm that DON can maintain chlorophyll content in darkness but that $\mathrm{Ca}\left(\mathrm{NO}_{3}\right)_{2}$ neither enhanced the effect of DON nor, by itself, affected chlorophyll content.
Chlorophylls a and b and carotenoids. To learn if DON altered content of chlorophyll $\mathrm{b}$ and carotenoid pigments in the same temporal pattern as that for chlorophyll a, we determined amounts of the three pigments spectrophotometrically in leaf extracts. The experiment was done with DON at 0,10 , and $30 \mathrm{ppm}$ in combination with $\mathrm{Ca}\left(\mathrm{NO}_{3}\right)_{2}$. Treated segments were incubated in light and samples taken at 12, 24, 48, and $72 \mathrm{~h}$.

DON had no effect at $12 \mathrm{~h}$. At 24 to $72 \mathrm{~h}$, however, DON at $30 \mathrm{ppm}$ in light reduced content of all three pigments in patterns similar to the change described earlier for relative chlorophyll content. Content of chlorophyll $\mathrm{b}$ and carotenoid pigments was reduced in amounts proportional to reduction in chlorophyll a. With 10 ppm DON, chlorophyll b was also reduced in proportion to chlorophyll a, but carotenoid pigment content was not reduced compared to controls with 0 ppm DON. In darkness, $30 \mathrm{ppm}$ DON preserved content of the three pigments through $72 \mathrm{~h}$ at levels near amounts present at $24 \mathrm{~h}$. DON at $10 \mathrm{ppm}$ also preserved the pigments through $48 \mathrm{~h}$ but amounts declined somewhat by $72 \mathrm{~h}$.

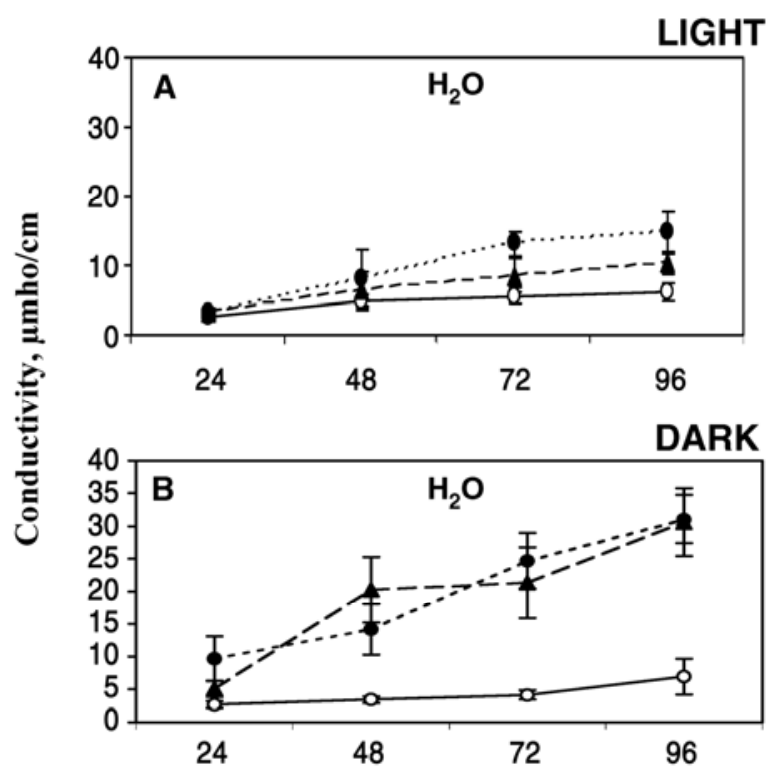

Duration of treatment, hr

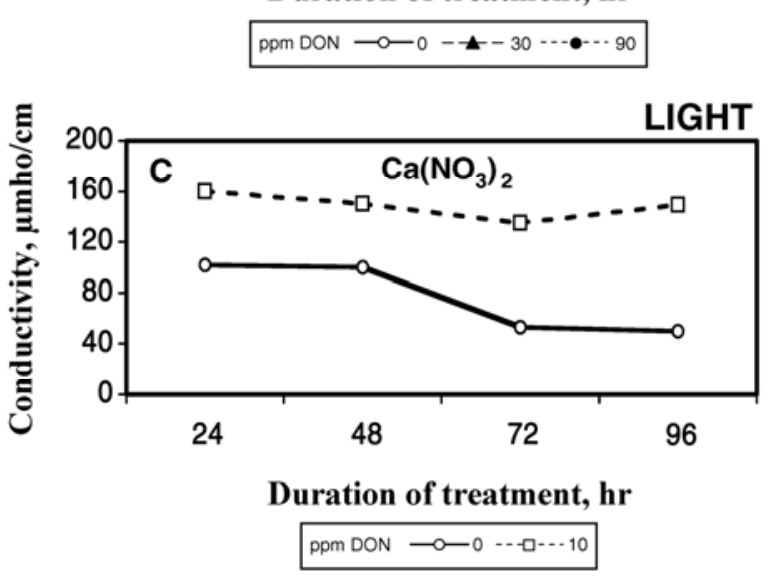

Fig. 3. Conductivity $(\mu \mathrm{mho} / \mathrm{cm})$ of deoxynivalenol (DON) solutions on which leaf segments were floated for 24 to $96 \mathrm{~h}$. Mean \pm S.E. A, Segments incubated in light on 0,30 , and $90 \mathrm{ppm}$ DON without $\mathrm{Ca}\left(\mathrm{NO}_{3}\right)_{2}$. DON at $90 \mathrm{ppm}$ differed significantly from 0 and $30 \mathrm{ppm}$ at $P=0.05$ (n $=3$ to 6 ). B, Same as A but incubated in dark. DON at 30 and $90 \mathrm{ppm}$ differed significantly from 0 ppm at $P=0.05(\mathrm{n}=3$ to 6$)$. C, Segments were incubated on 0 and $10 \mathrm{ppm}$ DON in light with $10 \mathrm{mM} \mathrm{Ca}\left(\mathrm{NO}_{3}\right)_{2}$ added to incubating solutions (unreplicated experiment). A and B, Significant differences were determined as for Figure 2. 
Electrolyte loss from DON-treated tissues. As an indicator of damage to DON-treated tissues, electrolyte leakage from leaf segments was determined by measuring the conductivity of solutions on which segments were floated. The solutions contained 0 , 30 , and 90 ppm DON, all without $\mathrm{Ca}\left(\mathrm{NO}_{3}\right)_{2}$. These incubating solutions initially had conductivity of $0.85 \pm 0.15 \mu \mathrm{mho} / \mathrm{cm}$. In light, conductivity increased slowly over 24 to $96 \mathrm{~h}$ for all treatments, but this increase was significantly greater for $90 \mathrm{ppm}$ than for 0 or $30 \mathrm{ppm} \mathrm{DON}$, reaching $13 \mu \mathrm{mho} / \mathrm{cm}$ (Fig. 3A). The segments on 30 to $90 \mathrm{ppm}$ DON had patches of white tissue as shown earlier. In darkness, conductivity also increased without DON, but more rapidly with both 30 and 90 ppm DON, reaching $31 \mu \mathrm{mho} / \mathrm{cm}$ by $96 \mathrm{~h}$ (Fig. 3B). The leaf segments remained fully green, again as described earlier. Thus, the green leaf segments in darkness suffered more electrolyte leakage than partially white segments in light.

Conductivity was also measured in an experiment with $10 \mathrm{mM}$ $\mathrm{Ca}\left(\mathrm{NO}_{3}\right)_{2}$ added to $10 \mathrm{ppm}$ DON. This increased initial values of incubating solutions to $100 \mu \mathrm{mho} / \mathrm{cm}$ with or without DON. Without DON, tissues stayed mostly green as the incubating solution remained at $100 \mu \mathrm{mho} / \mathrm{cm}$ for $48 \mathrm{~h}$, and then declined to $50 \mu \mathrm{mho} / \mathrm{cm}$ at 72 to $96 \mathrm{~h}$ (Fig. $3 \mathrm{C}$ ), as if ions from $\mathrm{Ca}\left(\mathrm{NO}_{3}\right)_{2}$ were taken up by the leaf segments. With $10 \mathrm{ppm}$ DON, tissues became white by $48 \mathrm{~h}$ as conductivity increased to $160 \mu \mathrm{mho} / \mathrm{cm}$ by $24 \mathrm{~h}$ and remained near that level through $96 \mathrm{~h}$ (Fig. 3C). Thus, these leaf segments released enough electrolytes to increase conductivity by $60 \mu \mathrm{mho} / \mathrm{cm}$ and possibly more if the segments took up ions from $\mathrm{Ca}\left(\mathrm{NO}_{3}\right)_{2}$ as apparently happened without DON. In either case, the net loss from leaf segments on $10 \mathrm{ppm}$ DON in light at 24 to $48 \mathrm{~h}$ was greater and earlier in the presence of $\mathrm{Ca}\left(\mathrm{NO}_{3}\right)_{2}$ (Fig. 3C) than the loss on $90 \mathrm{ppm}$ DON without it (Fig. 3A).

Uptake of Evans blue by DON-treated tissues. As a second way to evaluate damage in DON-treated leaf segments, we observed uptake of Evans blue microscopically. Leaf segments with portions of epidermis stripped away were floated on 10 and $30 \mathrm{ppm}$ DON supplemented with $10 \mathrm{mM} \mathrm{Ca}\left(\mathrm{NO}_{3}\right)_{2}$. After 12 to $72 \mathrm{~h}$, leaf segments were treated with Evans blue and examined for presence of the dye within mesophyll cells. In surface view, dye was visible in the lobes of the cells facing the exposed stripped surface of leaf segments. Each mesophyll cell usually had two or more lobes, but we could not discern which lobes belonged to a given cell. Consequently, dye uptake is presented for stained lobes as percentage of all lobes observed.

In control leaf segments not receiving DON, chloroplasts lined the walls of mesophyll lobes (Fig. 4A). A few lobes stained with Evans blue but always in less than $15 \%$ of all lobes (data not shown). After $12 \mathrm{~h}$ of treatment with 10 or $30 \mathrm{ppm}$ DON, Evans blue stained 40 to $50 \%$ of lobes light blue, sometimes staining nuclei dark blue (as shown for $30 \mathrm{ppm}$ DON, Fig. 4B). At this time, some chloroplasts were displaced from their usual position along the cell wall (not shown). After $18 \mathrm{~h}$ of treatment, 67 to $75 \%$ of lobes were stained and chloroplasts were frequently displaced from lobe walls, as shown for $10 \mathrm{ppm}$ DON (Fig. 4C). After 48 to 72 h, 62 to $100 \%$ of lobes were stained and lobe contents appeared to be degenerate, exhibiting vacuolated vestiges of cytoplasm and chloroplasts as shown for $30 \mathrm{ppm}$ DON at $48 \mathrm{~h}$ (Fig. 4D). However, a few darkly stained nuclei remained (not shown).

In darkness, results were similar to those in light. With $30 \mathrm{ppm}$ DON, for example, $51 \%$ of lobes were stained after $12 \mathrm{~h}, 75 \%$
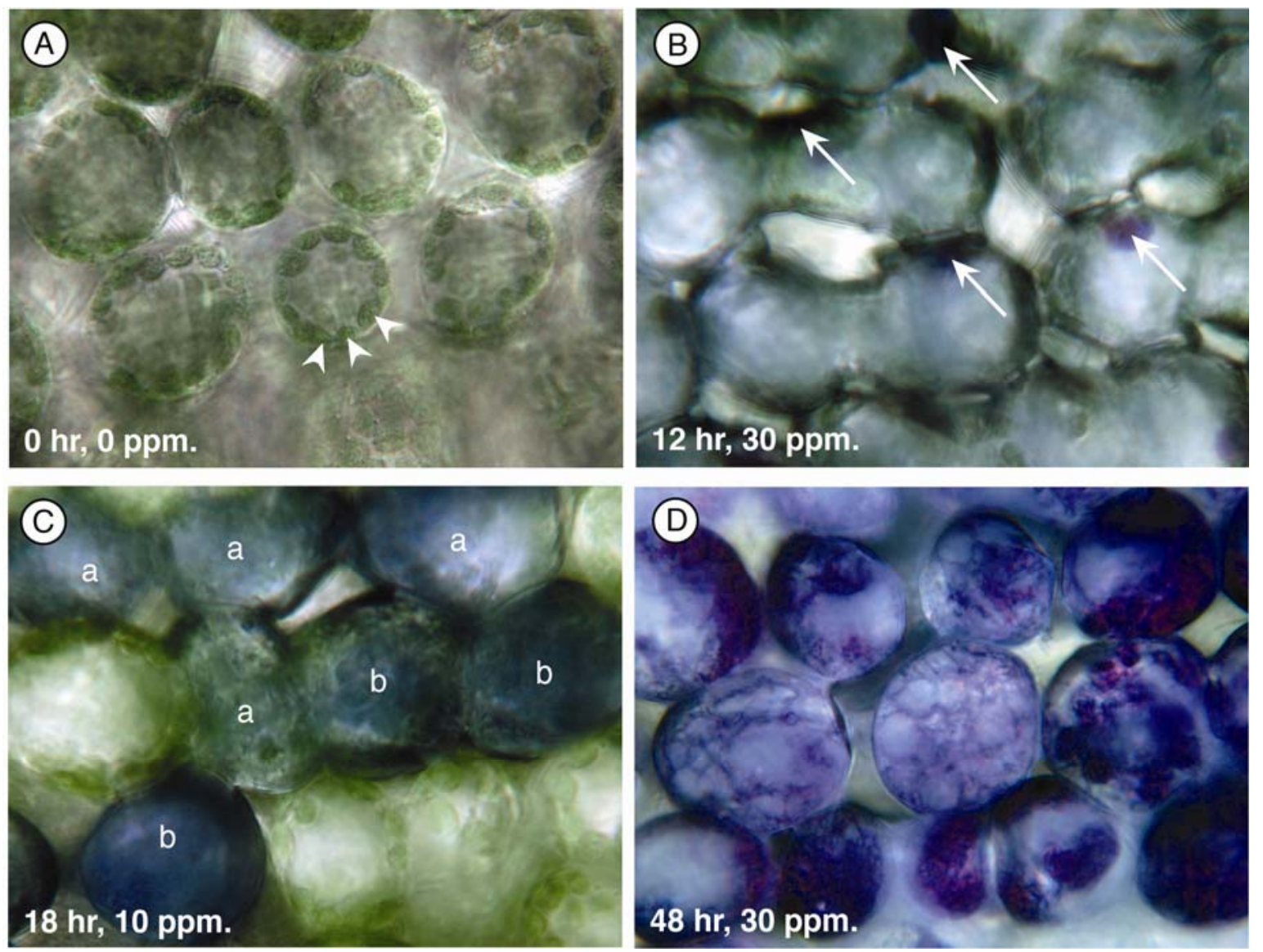

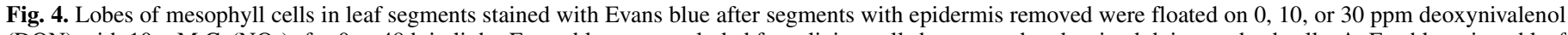

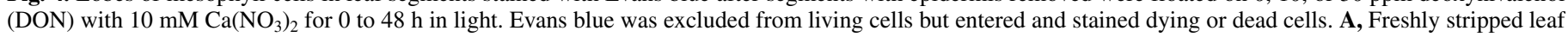

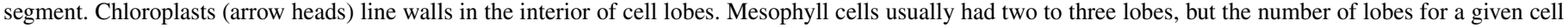

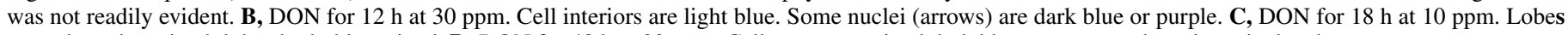
a, moderately stained; lobes b, darkly stained. D, DON for $48 \mathrm{~h}$ at $30 \mathrm{ppm}$. Cell contents stained dark blue; some cytoplasm is vesiculated. 
after $18 \mathrm{~h}$, and $100 \%$ after $48 \mathrm{~h}$. Thus, in both light and dark, DON rendered cells permeable to Evans blue. In both light and dark, the effect was detected within 12 to $18 \mathrm{~h}$ of treatment.

DON concentration in treated leaf segments. The concentration of DON within leaf segments treated with $30 \mathrm{ppm}$ DON was measured after 12 to $48 \mathrm{~h}$. When DON was applied with $\mathrm{Ca}\left(\mathrm{NO}_{3}\right)_{2}$, results were similar in light and dark. At $12 \mathrm{~h}$, segments contained $8.8 \pm 0.8 \mathrm{ppm}$ DON in light and $8.7 \pm 0.3 \mathrm{ppm}$ in darkness. At $48 \mathrm{~h}$, values increased to $14.7 \pm 1.2 \mathrm{ppm}$ in light and $13.4 \pm 2.4$ ppm in darkness. Without $\mathrm{Ca}\left(\mathrm{NO}_{3}\right)_{2}$, segments were again treated with $30 \mathrm{ppm}$ DON but incubated only in light. At $12 \mathrm{~h}$, the segments contained DON at $11.7 \pm 1.8 \mathrm{ppm}$. At $48 \mathrm{~h}$, they contained DON at $10.9 \pm 1.0 \mathrm{ppm}$. Thus, DON content in light did not increase by $48 \mathrm{~h}$ as it did with $\mathrm{Ca}\left(\mathrm{NO}_{3}\right)_{2}$.

\section{DISCUSSION}

Against a background of gradual chlorophyll loss in detached leaf segments, we detected two opposing effects of DON that are relevant to potential roles in FHB. Treatments that were toxic, as judged by loss of electrolytes from leaf tissues and by Evans blue uptake, had a light-dependent bleaching effect expressed by loss in content of nearly all chlorophyll and carotenoid pigments. The effect was similar to bleaching in lesions produced in the palea and lemma of barley florets in FHB $(6,31)$. Furthermore, the bleached areas sometimes had brown borders which resembled rings found around lesions on the palea and lemma in FHB $(6,31)$. On the other hand, DON treatments that were not toxic, depending on DON concentration and other experimental factors, caused no injury but tended to prevent the gradual reduction in chlorophyll content of detached leaf segments. In these cases, DON delayed the senescence triggered by detachment.

When senescence was delayed in response to subtoxic concentrations of DON, such as 30 ppm applied without $\mathrm{Ca}^{2+}$, chloroplasts, tonoplasts, and plasmalemmas remained intact as viewed by transmission electron microscopy (TEM) (7; W. Bushnell, D. Krueger, and T. Seeland, unpublished data). Ultrastructure of leaf cells was similar to that of freshly detached leaf segments. Cycloheximide, which like DON inhibits protein synthesis, also delayed senescence of barley leaf segments in our experiments, much as reported for detached oat leaves $(33,47,50)$. With respect to $\mathrm{FHB}$, we speculate that DON at subtoxic levels in the lemma and palea of infected floret tissues may have an effect similar to senescence delay, maintaining metabolic activity favorable for the initial biotrophic stage of disease development when the fungus interacts with living cells of the barley floret (6).

DON kept tissues green in two other experimental situations, although results in these cases are unlikely to be relevant to FHB. On one hand, leaf segments injured by toxic concentrations of DON remained green if the segments were incubated in darkness. Photooxidation of chlorophyll did not take place in the injured cells. This would not happen with respect to DON produced in FHB under daily periods of sunlight in the field. The second situation involved treatments in light with DON at much higher concentrations than normally required for toxicity, such as 90 ppm without $\mathrm{Ca}^{2+}$. In this case, high DON concentrations seemed to override toxic effects, allowing expression of senescence delay. This anomalous effect seemingly could not occur in FHB, since DON would injure host tissues before reaching concentrations high enough to suppress toxicity.

The bleaching effect involving loss of chlorophyll and carotenoid pigments has not been reported for DON or other trichothecene toxins, except Desjardins et al. (12) show a white leaf of Arabidopsis after treatment with an unidentified trichothecene toxin. However, reported symptoms of DON and other trichothecene toxins include yellowing, browning, and necrosis as noted earlier. In our experiments, tissues treated with toxic concentrations of DON lost chlorophyll $\mathrm{a}$ and $\mathrm{b}$ and carotenoid pigments in similar temporal patterns, except for negligible effects on carotenoid pigments at low DON concentrations (10 ppm). This loss of pigment was associated with degeneration of chloroplasts which was preceded by damage to tonoplasts and plasmalemmas (7), indicating that chloroplast degeneration was not a primary response to DON. Loss of electrolytes from DON-treated barley leaf tissues also indicated damage to the plasmalemma, much as reported for maize, muskmelon, and wheat $(9,14,29,30)$. Membrane damage was also indicated by uptake of Evans blue in our experiments and by uptake of trypan blue in experiments with wheat (14). In darkness where DON-treated leaf segments remained fully green, tissues also leaked electrolytes and stained with Evans blue. Thus, damage to the plasmalemma was independent of light and pigment loss. Loss of pigment, on the other hand, was a secondary effect dependent on light but not required for toxicity.

The pronounced enhancement of DON toxicity by $\mathrm{Ca}\left(\mathrm{NO}_{3}\right)_{2}$ in our experiments can be attributed to $\mathrm{Ca}^{2+}$ since $\mathrm{CaCl}_{2}$ was effective and $\mathrm{KNO}_{3}$ was not. $\mathrm{Ca}^{2+}$ had no effect on DON uptake at $12 \mathrm{~h}$ when damage to the plasmalemma was first detected by Evans blue uptake, although $\mathrm{Ca}^{2+}$ increased DON uptake at $48 \mathrm{~h}$, possibly as a response to damage caused by the toxin. Otherwise, mechanisms of $\mathrm{Ca}^{2+}$ action remain to be investigated. Nevertheless, our results with leaf tissues suggest that amounts of available $\mathrm{Ca}^{2+}$ are likely to influence toxicity of DON produced in the palea, lemma, and caryopsis as FHB develops. Likewise, $\mathrm{Ca}^{2+}$ may enhance toxicity in kernels, roots, leaves, and callus tissues used in bioassays to determine sensitivity of plants to DON.

Although not a trichothecene, the mycotoxin fumonisin $\mathrm{B}_{1}$ produced by $F$. verticillioides ( $F$. moniliforme) caused photobleaching and electrolyte leakage in jimsonweed leaves (1). Results were remarkably similar to the effects of DON in barley leaves. However, fumonisin $\mathrm{B}_{1}$ does not inhibit protein synthesis. Instead, it inhibits ceramide synthesis, disrupting sphingolipid metabolism (2). From examination of fumonisin-treated jimsonweed leaf tissues by TEM, Abbas et al. (1) concluded that membrane disruption may lead to loss of metabolic processes that normally protect chloroplast pigments, which is consistent with the sequence of events initiated by DON.

Cycloheximide, which inhibits protein synthesis in cytoplasmic ribosomes, had a dual effect much like DON in detached barley leaf segments. Low concentrations delayed senescence as discussed earlier; higher concentrations caused photobleaching, an effect not reported for cycloheximide. The similarity of their effects suggests that both DON and cycloheximide initiate events leading to senescence delay or photobleaching by inhibiting protein synthesis in cytoplasm. In contrast, chloramphenicol, an inhibitor of protein synthesis in chloroplasts (47), produced little or no bleaching in barley leaf segments in our experiments.

One emerging possibility is that inhibition of protein synthesis by DON initiates PCD. Cycloheximide and other inhibitors of protein synthesis have induced PCD (apoptosis) in animal cells $(28,41,49)$. Laddering of genomic DNA indicated DON induced PCD in wheat leaves (14) as did induction of transcripts of genes involved in PCD (4). PCD, as a response of barley leaf tissue to DON, is suggested by the loss of the tonoplast as an initial event leading to cell death (7). Loss of this membrane is a key primary event in plant PCD $(19,23,27)$. Furthermore, uptake of $\mathrm{Ca}^{2+}$ into cytosol is a requirement for plant PCD $(24,27)$, consistent with the enhanced toxicity of DON by addition of $\mathrm{Ca}^{2+}$ in our experiments. Finally, fumonisin $\mathrm{B}_{1}$, which parallels DON in effects on leaf tissues, induces PCD in plant and animal cells (3,22). PCD is postulated to be induced generally in plant diseases caused by necrotrophic pathogens $(17,21,48)$.

The results here add to the list of ways that DON affects plant tissues. Bleaching provides visual evidence of degradation of chloroplasts and other components of cells, possibly as a result of PCD. Senescence delay indicates DON activates a response 
separate from that leading to cell death. DON also has several other nontoxic effects, such as inhibition of cell division and growth as reviewed earlier, and inhibition of cell wall thickening formed as a defense response (26) and, conversely, activation of defense response genes (4). With potential for many varied effects, the roles of DON in development of FHB are likely to be multiple and complex. Regardless of this diversity of effects and of the precise sequence of events leading to loss of chloroplast pigments, bleaching is potentially useful as an indicator of the toxic effects of DON. For example, bleaching could be used for measuring differences in sensitivity to DON among barley genotypes. Any trials involving bleaching need to be done in light, preferably with attention to availability of $\mathrm{Ca}^{2+}$.

\section{ACKNOWLEDGMENTS}

This material is based upon work supported by the Wheat and Barley Scab Initiative of the Agricultural Research Service, U.S. Department of Agriculture. Mention of a trademark or proprietary product does not constitute a guarantee or warranty of the product by the U.S. Department of Agriculture or the University of Minnesota and does not imply its approval to the exclusion of other products that also may be suitable. Any opinions, findings, conclusions, or recommendations expressed in this publication are those of the authors and do not necessarily reflect the view of the U.S. Department of Agriculture or the University of Minnesota. We thank Y. Dong and W. Xie for analysis of DON content in leaf samples; L. Lendway of the Statistical Clinic, University of Minnesota, and C. Brown who assisted in statistical analysis of data; J. Morrison for excellent graphics; A. Bushnell for word processing; Y. Dong, K. Evans, J. Kolmer, K. Leonard, and S. Lewandowski for kindly reviewing the manuscript; and A. M. Jones for helpful discussion of the research.

\section{LITERATURE CITED}

1. Abbas, H. K., Paul, R. N., Boyette, C. D., Duke, S. O., and Vesonder, R. F. 1992. Physiological and ultrastructural effects of fumonisin on jimsonweed leaves. Can. J. Bot. 70:1824-1833.

2. Abbas, H. K., Tanaka, T., Duke, S. O., Porter, J. K., Wray, E. M., Hodges, L., Sessions, A. E., Wang, E., Merrill, A. H., Jr., and Riley, R. T. 1994. Fumonisin- and AAL-toxin-induced disruption of sphingolipid metabolism with accumulation of free sphingoid bases. Plant Physiol. 106:10851093.

3. Asai, T., Stone, J. M., Heard, J. E., Kovtun, Y., Yorgey, P., Sheen, J., and Ausubel, F. M. 2000. Fumonisin B1-induced cell death in Arabidopsis protoplasts requires jasmonate-, ethylene-, and salicylate-dependent signaling pathways. Plant Cell 12:1823-1836.

4. Boddu, J., Cho, S., and Muehlbauer, G. J. 2007. Transcriptome analysis of trichothecene-induced gene expression in barley. Mol. Plant-Microbe Interact. 20:1364-1375.

5. Bruins, M. B. M., Karsaï, I., Schepers, J., and Snijders, C. H. A. 1993. Phytotoxicity of deoxynivalenol to wheat tissue with regard to in vitro selection for Fusarium head blight resistance. Plant Sci. 94:195-206.

6. Bushnell, W. R., Hazen, B. E., and Pritsch, C. 2003. Histology and physiology of Fusarium head blight. Pages 44-83 in: Fusarium Head Blight of Wheat and Barley. K. J. Leonard and W. R. Bushnell, eds. The American Phytopathological Society, St. Paul, MN.

7. Bushnell, W. R., Seeland, T. M., Perkins-Veazie, P., Krueger, D. E., Collins, J., and Russo, V. M. 2005. The effects of deoxynivalenol on barley leaf tissues. Pages 270-284 in: Genomic and Genetic Analysis of Plant Parasitism and Defense. S. Tsuyumu, J. E. Leach, T. Shiraishi, and T. Wolpert, eds. The American Phytopathological Society, St. Paul, MN.

8. Casale, W. L., and Hart, L. P. 1988. Inhibition of ${ }^{3} \mathrm{H}$-leucine incorporation by trichothecene mycotoxins in maize and wheat tissue. Phytopathology 78:1673-1677.

9. Cossette, F., and Miller, J. D. 1995. Phytotoxic effect of deoxynivalenol and Gibberella ear rot resistance of corn. Natural Toxins 3:383-388.

10. Cutler, H. G., and Jarvis, B. B. 1985. Preliminary observations on the effects of macrocyclic trichothecenes on plant growth. Environ. Exp. Bot. 25:115-128.

11. Desjardins, A. E. 2006. Pages 13-64 in: Fusarium Mycotoxins, Chemistry, Genetics, and Biology. The American Phytopathological Society, St. Paul, MN.

12. Desjardins, A. E., McCormick, S. P., and Appell, M. 2007. Structureactivity relationships of trichothecene toxins in an Arabidopsis thaliana leaf assay. J. Agric. Food Chem. 55:6487-6492.
13. Desjardins, A. E., Proctor, R. H., Bai, G., McCormick, S. P., Shannon, G., Beuchley, G., and Hohn, T. M. 1996. Reduced virulence of trichothecenenonproducing mutants of Gibberella zeae in wheat field tests. Mol. PlantMicrobe Interact. 9:775-781.

14. Desmond, O. J., Manners, J. M., Stephens, A. E., Maclean, D. J., Schenk, P. M., Gardiner, D. M., Munn, A. L., and Kazan, K. 2008. The Fusarium mycotoxin deoxynivalenol elicits hydrogen peroxide production, programmed cell death and defence responses in wheat. Mol. Plant Pathol. 9:435-445.

15. Dexter, J. E. and Nowicki, T. W. 2003. Safety assurance and quality assurance issues associated with Fusarium head blight in wheat. Pages 420-460 in: Fusarium Head Blight of Wheat and Barley. K. J. Leonard and W. R. Bushnell, eds. The American Phytopathological Society, St. Paul, MN.

16. Di, R., and Tumer, N. E. 2005. Expression of a truncated form of ribosomal protein L3 confers resistance to pokeweed antiviral protein and the Fusarium mycotoxin deoxynivalenol. Mol. Plant-Microbe Interact. 18:762-770.

17. Dickman, M. B., and Reed, J. C. 2004. Paradigms of programmed cell death in animals and plants. Pages 26-43 in: Programmed Cell Death in Plants. J. Gray, ed., Blackwell Publishing, CRC Press, Boca Raton, FL.

18. Eudes, F., Comeau, A., Rioux, S., and Collin, J. 2001. Impact of trichothecenes on Fusarium head blight [Fusarium graminearum] development in spring wheat (Triticum aestivum). Can. J. Plant Pathol. 23:318-322.

19. Fukuda, H. 2000. Programmed cell death of tracheary elements as a paradigm in plants. Plant Mol. Biol. 44:245-253.

20. Gaff, D. F., and Okang'o-Ogola, O. 1971. The use of non-permeating pigments for testing the survival of cells. J. Exp. Bot. 22:756-758.

21. Gechev, T. S., Gadjev, I. Z., and Hille, J. 2004. An extensive microarray analysis of AAL-toxin-induced cell death in Arabidopsis thaliana brings new insights into the complexity of programmed cell death in plants. Cell. Mol. Life Sci. 61:1185-1197.

22. Gilchrist, D. G. 1998. Programmed cell death in plant disease: The purpose and promise of cellular suicide. Annu. Rev. Phytopathol. 36:393414.

23. Groover, A., DeWitt, N., Heidel, A., and Jones, A. 1997. Programmed cell death of plant tracheary elements differentiating in vitro. Protoplasma 196:197-211.

24. Groover, A., and Jones, A. M. 1999. Tracheary element differentiation uses a novel mechanism coordinating programmed cell death and secondary cell wall synthesis. Plant Physiol. 119:375-384.

25. Harris, L. J., and Gleddie, S. C. 2001. A modified Rpl3 gene from rice confers tolerance of the Fusarium graminearum mycotoxin deoxynivalenol to transgenic tobacco. Physiol. Mol. Plant Pathol. 58:173-181.

26. Jansen, C., von Wettstein, D., Schäfer, W., Kogel, K.-H., Felk, A., and Maier, F. J. 2005. Infection patterns in barley and wheat spikes inoculated with wild-type and trichodiene synthase gene disrupted Fusarium graminearum. Proc. Natl. Acad. Sci. 102:16892-16897.

27. Jones, A. M. 2001. Programmed cell death in development and defense. Plant Physiol.125:94-97.

28. Kochi, S. K., and Collier, R. J. 1993. DNA fragmentation and cytolysis in U937 cells treated with diphtheria toxin or other inhibitors of protein synthesis. Exp. Cell Res. 208:296-302.

29. Kuti, J. O., and Ng, T. J. 1987. Phytotoxic effects of trichothecene metabolites from pathogenic strains of Myrothecium roridum on Cucumis melo L. Biodeterioration Res.1:213-222.

30. Kuti, J. O., Ng, T. J., and Bean, G. A. 1989. Possible involvement of a pathogen-produced trichothecene metabolite in Myrothecium leaf spot of muskmelon. Physiol. Mol. Plant Pathol. 34:41-54.

31. Lewandowski, S. M., Bushnell, W. R., and Evans, C. K. 2006. Distribution of mycelial colonies and lesions in field-grown barley inoculated with Fusarium graminearum. Phytopathology 96:567-581.

32. Lichtenthaler, H. K., and Buschmann, C. 2001. Extraction of photosynthetic tissues: Chlorophylls and carotenoids. Pages F4.2.1-F4.2.6 in: Current Protocols in Food Analytical Chemistry. R. E. Wrolstad, T. E. Acree, H. An, E. A. Decker, M. H. Penner, D. S. Reid, S. J. Schwartz, C. F. Shoemaker, and P. Sporns, eds. John Wiley \& Sons, New York.

33. Martin, C., and Thimann, K. V. 1972. The role of protein synthesis in the senescence of leaves. Plant Physiol. 49:64-71.

34. Masuda, D., Ishida, M., Yamaguchi, K., Yamaguchi, I., Kimura, M., and Nishiuchi, T. 2007. Phytotoxic effects of trichothecenes on the growth and morphology of Arabidopsis thaliana. J. Exp. Bot. 58:1617-1626.

35. McLean, M. 1996. The phytotoxicity of Fusarium metabolites: An update since 1989. Mycopathologia 133:163-179.

36. Mirocha, C. J., Kolaczkowski, E., Xie, W., Yu, H., and Jelen, H. 1998. Analysis of deoxynivalenol and its derivatives (batch and single kernel) using gas chromatography/mass spectrometry. J. Agric. Food Chem. 46:1414-1418.

37. Mitterbauer, R., Poppenberger, B., Raditschnig, A., Lucyshyn, D., Lemmens, M., Glössl, J., and Adam, G. 2004. Toxin-dependent utilization 
of engineered ribosomal protein L3 limits trichothecene resistance in transgenic plants. Plant Biotechnol. J. 2:329-340.

38. Nishiuchi, T., Masuda, D., Nakashita, H., Ichimura, K., Shinozaki, K., Yoshida, S., Kimura, M., Yamaguchi, I., and Yamaguchi, K. 2006. Fusarium phytotoxin trichothecenes have an elicitor-like activity in Arabidopsis thaliana, but the activity differed significantly among their molecular species. Mol. Plant-Microbe Interact. 19:512-520.

39. Packa, D. 1991. Cytogenetic changes in plant cells as influenced by mycotoxins. Mycotoxin Res. 7:150-155

40. Pestka, J. J. 2008. Mechanisms of deoxynivalenol-induced gene expression and apoptosis. Food Additives Contaminants 25:1128-1140.

41. Pestka, J. J., Yan, D., and King, L. E. 1994. Flow cytometric analysis of the effects of in vitro exposure to vomitoxin (deoxynivalenol) on apoptosis in murine T, B and IgA ${ }^{+}$cells. Food. Chem. Toxicol. 32:1125-1136.

42. Rocha, O., Ansari, K., and Doohan, F. M. 2005. Effects of trichothecene mycotoxins on eukaryotic cells: A review. Food Additives Contaminants 22:369-378.

43. Shaner, G. 2003. Epidemiology of Fusarium head blight of small grain cereals in North America. Pages 84-119 in: Fusarium Head Blight of Wheat and Barley. K. J. Leonard and W. R. Bushnell, eds. The American Phytopathological Society, St. Paul, MN.

44. Shimada, T., and Otani, M. 1990. Effects of Fusarium mycotoxins on the growth of shoots and roots at germination in some Japanese wheat cultivars. Cereal Res. Communications 18:229-232.

45. Steffenson, B. J. 2003. Fusarium head blight of barley: Impact, epidemics, management, and strategies for identifying and utilizing genetic resistance. Pages 241-295 in: Fusarium Head Blight of Wheat and Barley. K. J. Leonard and W. R. Bushnell, eds. The American Phytopathological Society, St. Paul, MN.

46. Tada, Y., Hata, S., Takata, Y., Nakayashiki, H., Tosa, Y., and Mayama, S. 2001. Induction and signaling of an apoptotic response typified by DNA laddering in the defense response of oats to infection and elicitors. Mol. Plant-Microbe Interact. 14:477-486.

47. Thomas, H. 1976. Delayed senescence in leaves treated with the protein synthesis inhibitor MDMP. Plant Sci. Lett. 6:369-377.

48. Wolpert, T. J., Lorang, J. M., Curtis, M. J., Coffeen, W. C., Carkaci-Salli, N., and Sweat, T. A. 2005. Programmed cell death in the disease response. Pages 207-218 in: Genomic and Genetic Analysis of Plant Parasitism and Defense. S. Tsuyumu, J. E. Leach, T. Shiraishi, and T. Wolpert, eds. The American Phytopathological Society, St. Paul, MN.

49. Yang, G.-H., Jarvis, B. B., Chung, Y.-J., and Pestka, J. J. 2000. Apoptosis induction by the satratoxins and other trichothecene mycotoxins: Relationship to ERK, p38 MAPK, and SAPK/JNK activation. Toxicol. Appl. Pharmacol. 164:149-160.

50. Yu, S. M., and Kao, C. H. 1981. Retardation of leaf senescence by inhibitors of RNA and protein synthesis. Physiol. Plant 52:207-210. 